\title{
New Russian Cinema
}

\author{
By Christina Stojanova
}

Fall 1998 Issue of KINEMA

The transition to market economy and the dismantling of the USSR created an unprecedented crisis in Russian film industry. The awesome All Union Ministry of Cinematography (Goskino) was dismembered. This almost paramilitary institution, whose senior officials were also allegedly senior KGB officers, directed, or rather policed, the Soviet film production process with the stick of censorship, and the carrot of lucrative awards. Understandably, the censorship is not going to be sorely missed. What is missed, however, are the generous state budgets and the firm general line, drawn by the military from the Ministry, in accordance with the ever-changing Kremlin ideological vision.

Distribution-wise the situation in Russian cinema followed the pattern characteristic for the other postcommunist countries. American films, kept for so long beyond the ideological pale, took over the repertoire, occupying around $75 \%$ of the programming time, with a tendency to reach $85 \%$ during the next decade. In the Russian Federation, the number of film theatres has dwindled from 3,000 to 1,500, and continues to fall.

After the production boom from the early 1990s (300 films for 1991-92 alone), the figure has stabilised around 50-60 per year. To say that the government has entirely ceased to finance Russian cinema will be wrong. But the traditional mismanagement of state funding, the need to support an enormous army of redundant administrators, and pay salaries to non-working, tenured film-makers, renders government funding far from sufficient vis-à-vis runaway inflation and constantly rising costs.

One explanation of the initial film-production boom is that the film industry offered the first ever possibilities for privatisation and legal investment. Another explanation, or rather a rumour, is that the budding Russian Mafia used film production for money laundering.

The New Russian businessmen, however, gave up on film soon after Gaidar's government introduced in 1993 valorous legal venues for privatisation and investments. As for Mafiosi -- they quickly realised that film producing was not worth the effort, and even the most expensive blockbuster ensures only a modest money laundering operation.

While enthusiasm with artistic (and entrepreneurial) freedom was running high in unexpected quarters, boosting quantity over quality, more experienced Russian filmmakers saw the salvation of Russian cinema in the hands of Western investors.

The beginning was rather encouraging. The films, exposing the lower depths of Soviet reality and penetrating into the mysterious Russian soul, were met with real enthusiasm by Western audiences. It seemed that no visual excess (Alexander Sokurov's Days of Eclipse, 1988, Visitor Of A Museum, 1989, by Konstantin Lopushansky), no lapse into explicit naturalism (Bouge pas, Meurs et Resuscite, 1990, Vitali Kanevsky) or intensity of social conflicts (Taxi Blues, 1990, by Pavel Lungin, Sergei Bodrov's Freedom Is Paradise, 1989), were extreme enough to satisfy the hunger for more knowledge about post-perestroika Russia. Russian films were hot item at most prestigious international festivals. Films that were made without foreign financial participation would immediately find We stern distributors.

The time of euphoria ended with a rough awakening. Most Russian directors became increasingly reluctant to succumb to producers and their impossible demands. The magic formula of a universally marketable hybrid, made with Western money and Russian artistic sensitivity seemed impossible to find. Those who did bend under the pressure, never repeated the success of earlier films that made them famous. The subsequent works of Kanevsky, Lungin and Bodrov (Independent Life, Luna Park and Russians, respectively, all from 1992) teemed with recycled images and ideas from their previous works.

Naturally, the co-operation with foreign producers continues. French producers seem to have a special affinity for Russia, and the films usually reflect this benevolent spirit of co-operation (Burnt By the Sun, 1994 by Nikita Mikhalkov and Window in Paris, 1994 by J. Mamin). The co-production, however, has lost its exclusive status as the shortest cut to fame and glory, and is being treated for what it is -- an arduous business partnership. 
The good news is that Russia's own neophyte producers, private sponsors and investors have recently appeared to save the day. They certainly are not Mafiosi with a hidden agenda but cinephiles with money. On the other hand, as Nikita Mikhalkov rightfully noted, "there is no 'clean' money in today's Russia!" There is nothing wrong, indeed, if some newly acquired wealth is spent on keeping the national culture going, instead of being mindlessly wasted in Côte d'azur.

\section{The First Avant-garde and the Passion For Destruction}

The vanishing of the Kremlin ideological imperative caused a serious crisis in the New Russian Cinema much graver than the dismantling of the generous state budget. The general line used to create order in the communist world of ideas. It compelled filmmakers to take a stand: abide by it and get carrots, or step beyond it and get the stick. In the early '90s, however, it became relatively easier to raise money for a film than to think of ideas and stories.

Most established directors chose to wait for a couple of years until the dust settled. Sokurov, for example, remembered his early career and returned to documentary film-making. The younger and the inexperienced were naturally eager to test the limits of the newly acquired freedom before a new set of ideological restrictions bolted the door. St. Petersburg's Lenfilm studio took the lead. In comparison to Mosfilm, Lenfilm has always enjoyed the reputation of being ideologically the more open studio. It is no coincidence that Sokurov has made all his films at Lenfilm.

The directors from the first, or perestroika, avant-garde (1984-1989) were busy breaking taboos -- from political and ideological to sexual, necromantic and scatological. Theirs were predominantly short films -from 4 to 20 minutes, low budget and produced in cinema-clubs. The most notorious and radical trend is necrorealism. Evgeni Jufit is its father and also the non-contested leader of Leningrad's underground. In 1985 he made Hospital Attendants-Werewolves, a manifesto of necrorealist aesthetics, produced by the independent Mzhalalafilm studio he founded himself in 1984. It was followed by a few short works in the same naturalistic-nihilistic vein. Later he made his first feature length film, Daddy, Father Christmas Is Dead (1991) -- a sadomasochistic tale of psychological perversion, resulting in physical mutation of the human species.

\section{The Second Avant-garde and the Obsession With Remakes}

The second avant-garde (1989-1995) came after perestroika and deployed a frontal attack against "daddy's cinema". This attack targeted two fronts -- the idols of totalitarianism, and the patriarchal status quo -- in art and society. The attack was marshalled under the closest guidance of the Russian Film Critics Guild. One should be reminded that the New Russian Critics -- as better informed and well-travelled people -have been playing a vital role in the New Russian Cinema. They have encouraged, scripted, consulted, even directed experimental films. The New Russian Critics are a powerful and strong-minded lot and have made themselves indispensable in shaping all radical trends.

The second avant-garde was launched with parodies of Soviet film classics. Young directors were exorcising the awesome myths of classic Soviet cinema through witty games of free association. These films are hermetic and inaccessible for lay viewers for they served mostly as group therapy for post-communist filmmakers. They were also meant not to entertain, but to relieve the New Russian Cinema from its fears and complexes. In Comrade Tchkalov's Passage Across The North Pole (M. Pezhemsky, 1990), the famous Soviet explorer Valery Tchkalov is crawling towards the North Pole, dragging the psychoanalytic burden of Buñuel's Un chien Andalou. Animated frame by frame, the civil war hero Chapaev kisses the drowning Brezhnev, while Che Guevara descends from heaven on papier-mâché wings to rescue him. The excessive irony and blasphemy of such films ${ }^{(1)}$, however, are lost on audiences unfamiliar with the reverent pomposity of the originals. In this case, the film in question is Valery Tchkalov (Mikhail Kalatozov, 1941), a Communist cult movie and one of Stalin's favourites.

The centrepiece of this trend is Scorpion's Gardens (1991). It is written and directed by a prominent Russian critic -- Oleg Kovalov. He overcomes the trendy temptations of buffoonery à la Monty Python, reduces the avalanche of iconoclastic references, and gets down to business: to expose the sinister mechanism of totalitarian myth-making through cinema. He deconstructs not to ridicule, but to analyse. He takes apart a '50s detective movie, The Case With Corporal Kochetkov (A. Razumni, 1955), then edits its frames within the context of other spy films, musicals, as well as medical and propaganda documentaries from the ' 50 s. The 
unexpected montage juxtapositions enable Kovalov to analyse the mind of an ordinary man, manipulated by totalitarian propaganda. Brainwashed for years on end by relentless anti-Western fear-mongering, the hero is thrown into confusion by the thaw from the mid-1950s. His mind breaks down and turns into a battlefield between living and dead, thought and dogma, common sense and paranoia.

Despite its artistic clarity, the conceptual deconstruction of the totalitarian mind in Kovalov's film cannot be fully grasped without thorough knowledge of Soviet ideological and cultural mythology. And more important, without knowledge of the cruelty that sustained this mythology.

The subsequent films are more inclusive both geographically and culturally. They are made in Lenfilm and Mosfilm studios as well as in Almaty (Kazakhstan), and reclaim the severed cultural links with Western cinema.

Nicotine (1993), scripted by another prominent Russian critic, S. Dobrotvorsky, is a remake of Godard's Breathless, situated in present-day Leningrad. The plot and the structure of the original are preserved, but the adaptation of characters to a different social milieu have transformed the genre: from film noir to melodrama. Belmondo's character is a low class joyrider who steals a car and smokes Gitanes, shoots a cop, falls in love with a literary lady, and dies from a shotgun wound. While Jean Seberg's character quotes names and ideas, he measures his profile against Bogart's. His Russian counterpart is an upstart New Russian, who drives a fancy car, smokes trendy Montechristos, and while being persecuted by other Mafiosi, hangs out in the fashionable St. Petersburg's House of Cinema. He meets a snobbish starlet at a discussion of Breathless, attended personally by Godard. And while she flirts to make him jealous, he measures his profile against Belmondo's. She leaves him for an influential filmmaker. He is caught by Mafiosi.

The pleasure here lies in recognising Russian cultural signs, like the axe from Dostoyevski's Crime and Punishment; and in decoding the transformations suffered by Godard's original characters in the post-Soviet version -- which is difficult, if not impossible, without knowledge of New Russia's social mythology.

The triumph of the conceptual remake is Children Of Iron Gods (1993, T. Tat), an anti-utopia about the end of history. The young director (it is his first film) uses the visual language of communist mythology, but follows the grammar rules of classic adventure film genres, the Western and the Futuristic anti-utopia, to create a new conceptual meaning.

Amongst impressive ruins of gigantic steel works -- an icon of once great Soviet industry -- there lives a tribe of heavy drinking people. Like their ancestors from the early Middle Ages, they survive according to the law of jungle. Their main concern is how to get arms and vodka, and contemplate female flesh. The plot is centred on the upcoming wrestling tournament: Ignat, a hybrid between Superman, Russian folk tale Bogatyr, and socialist-realist "positive hero", is to fight on behalf of the steel workers' guild. His victory, however, is senseless. In spite of his strength and the respect he commands in the community, he -- contrary to his image -- is a puppet, manipulated by anonymous masters.

The director moves away from the anecdotal games, characteristic of the conceptual remake, to reveal the awesome prophecy of his tale. Ignat's masters have brought his world to destruction and continue their ruthless reign. The source of their power is a mysterious brief-case. It does not take long to recognise -even under the army fatigues -- familiar faces from Russia's current political elite. It is they and not the simple-minded strong man who are the real heroes on and off-screen.

The influence of Orwell's 1984 is strongly felt in Tat's film. The masters of the conceptual remake recognise Orwell, not Solzhenitsyn, as their literary inspiration. Hammer and Sickle (Sergei Livnev, 1995) relates to Animal Farm in viewing Soviet Union from the 1930s as Stalin's playground for social engineering. The metaphor of a case of enforced sex-change stands for Stalin's arrogant determination to subdue human nature. The film, however, fails to transcend the fixation with Stalinist myths, and remains on the surface of a human tragedy, hidden behind the (otherwise scrupulously reconstructed) lustrous totalitarian film aesthetics.

\section{The Fables of Transition to Responsibility}

As an integral part of the cultural elite, Russian film-makers have an exclusive sense of mission, and have always proudly considered themselves the consciousness of the nation. And while many are still obsessed with the fallen idols of totalitarianism, others have accepted the challenge to answer the eternal Russian question 
"What is to be done?" Should Russia follow its own Slavic path or take the Western way towards modernisation? It seems impossible to stay away from the notorious dispute between Westerners and Slavophiles, raging in Duma and dating back to the times when Peter the Great forced his grand boyars to cut off their beards as tribute to Westernisation. Taking sides in this dispute could be a risky enterprise for a film-maker. Nikita Mikhalkov, for example, was severely punished for his nationalist fling with the Slavophile political wing in Parliament. Russian critics met his film Burnt By the Sun with open contempt, which did not soften even after the film received an Oscar.

A post-modernist salon, on the other hand, has noisily proclaimed itself as the only proponent of Western values, thus alienating most of the filmmakers who happen to think and believe otherwise.

Andrei Konchalovsky made his contribution to the heated dispute about Russia's future with Ryaba, My Little Hen (1994). According to his pseudo-folk fable about the woes of transition to market economy, Russia should look for its own way out of the crisis. Liberalism and democracy are Western inventions, and are therefore alien to the Russian people. They will fail in Russia, as Marxism did.

Directors like Nikita Mikhalkov, Vadim Abdrashitov (Play For a Passenger, 1995), and Vladimir Khotinenko (The Muslim, 1995) prefer to ask first "What have we done?", before pondering what to do next. None of them offers a global solution. What emerges, however, is an attempt to see Russia's current spiritual and moral crisis as a cumulative effect of misguided best intentions and total absence of individual responsibility. It is not the West and its ideologies that have caused Russia's woes. It is not Ivan the Terrible, Peter the Great, neither Lenin nor Stalin. It is not God, not the Jews either. It is the fault of each and every Russian who has ignored his or her common sense in the name of grand delusions.

Against the backdrop of a huge portrait of Stalin, unfurled under the bright sun, the hand-cuffed enemy of the people, former Bolshevik Commander Kotov, breaks down at the realisation that he is a victim of his own deeds and in a way -- no better than his hired torturers. His noble social delusions have blinded him and turned him into a zealous instrument of the evil that is destroying him and his country (Burnt By the Sun).

Nikolay from Play For... is obsessed with revenge against the judge who had sent him to prison years ago. In the process, however, he inflicts much more suffering on himself and his loved ones than he could ever inflict on the malicious judge.

An Afghanistan war hero comes home after having been declared missing for years. His arrival causes a shock: he has become a Muslim. His life style has become so pious that he becomes an embarrassment for his family, for the village folks, possessed with post-perestroika consumerism, and for his war buddies who consider him traitor. The genre of these films could be loosely defined as moral parable, with a simple, somewhat apocalyptic message -- what goes around, comes around. This message could be also concisely expressed in any famous quote from the Bible: thou shalt not kill; whatsoever ye would that men should do to you, do ye even so to them; turn the other cheek; be thy brother's keeper.

In tune with the $19^{\text {th }}$ century Russian literary and artistic tradition, the presence of God is strongly felt in these films. God is the redeeming image of a fiery ball that crosses the frame at each crucial turn of the narrative (Burnt By the Sun). The mystical merge of personalities in Piece For... comes directly from Manichean Christianity. Nikolay takes the role of the judge, punishes the judge, becomes the judge. The chain of injustices is closed. The chastiser and the chastised, God and Devil, all in one.

In the grand eloquent mannerism of Mikhalkov's sensual universe, God is the absolute moral imperative existing outside the world of his characters. Whether they would recognise his existence or not is irrelevant to the deity's existence, while the act of religious awakening is purely a voluntary one, an expression of personal responsibility.

In Abdrashitov's ascetic world of pure reason, God is a higher moral principle, existing within his characters. They could choose to respect it and live in harmony with their conscience, or ignore it and face the consequences. The recognition of this higher principle is also a question of personal responsibility.

Not so, says Khotinenko. In his eclectic film experience, religion is a will power. It requires special energy to believe in God and become a responsible human being. It is a strenuous act, alienating most people. If you 
have the stamina to believe, you will find your God sooner or later. Khotinenko makes sure several times over that this is what he meant and has his Muslim to repeat it: "God is one, only His names are different!"

It is much safer for Mikhalkov and Abdrashitov to resolve issues of tragic or intentional guilt in clear-cut historical situations: the Great Terror from 1934-37 or the period of stagnation ('70s and '80s). Khotinenko's task is much more difficult -- he treads the volatile post-Soviet reality.

Khotinenko therefore prefers to create an original conflict situation and then watch it develop, without much venturing into philosophical or theological realms. He is brilliant, however, when examining the "idiocy" of village life or when revealing the mechanism of Russian xenophobia. The villagers openly hate the Muslim for being different and yet one of their own. But most of all they hate him for reminding them with his very presence how corrupt they are. Even his own mother says with reproach: "We know it is bad to steal, you do not have to remind us!"

Paradoxically, the Muslim is a post-modern reincarnation of Christ himself -- loving, forgiving, suffering for the sins of others, and finally murdered by them. But here Khotinenko's search for God runs out of steam. He cannot make his Muslim a Messiah since he doubts a priori his villagers' propensity for acts requiring will power -- they drift with the flow. And even if some of them do find stamina to believe, Khotinenko would not know what to do with them.

Khotinenko is reluctant to take any responsibility for the further developments in the life of the Muslim or the villagers. He has his hero killed, but somewhat reluctantly, to preserve his integrity. In any case, the Muslim is doomed both on the existential level and on the level of narrative. After all, what could he do with him if he stays alive and does wake pious feelings in the villagers? It would not have been a good idea considering the current political circumstances and all these tensions amongst Russians and Muslims in the former Soviet Republics. Khotinenko certainly would not have liked to see the villagers building a Muslim community or sending a regiment of volunteers to Bosnia -- he would not go for such cheap resolutions. That is why he leaves the advent of the Muslim and his death without any effect on the infantile villagers. They will go on stealing, lazing around, drinking themselves into oblivion, and waiting for another chance to find dollar bills swirling down the river. With the only difference that there will be no one around to point out how irresponsible they are. Only rarely, on a full moon night, they would wake up to the sight of a huge grinning head of a pig rising from the dark waters. It is unlikely, however, they would recognise their guilty conscience in it.

\section{The New Cinematic Image and the New Russians}

The hero of Limita (1994, Denis Yevstigneyev) is Ivan P. Voroshilov. He belongs to the marginal social stratum of the so-called limitchiki -- thus the title. He is a computer whiz, not indifferent to the redistribution of the New Russian wealth. The Russian initials of his name read VIP, and he stands up for it with a dangerous combination of primordial evil, high professionalism and personal charisma. With equal cool-ness he breaks a complicated computer code, steals a cheap can for the sake of stealing, purchases a river station, makes love to a pretty stranger, fights...

Yevstigneyev seems insensitive to the moral ambiguity of his characters. He sees them as the heroes of the New Barbarian Revolution and openly admires their cow-boy ethics. He is acquitting them with the same argument, used by the classic Soviet cinema from the '20s to acquit the ruthless Bolshevik commissars, or by the classic American cinema from the '30s to acquit the murderous depression gangsters. They restore social justice so they must be right. The visual leitmotif of the morning ritual dance says it all. It is a climactic self-assertion of the New Russians as masters in post-communist Russia. But it is also the ultimate triumph of the morally ambiguous New Cinematic Image over the preoccupation of the old, message-oriented Soviet Cinema.

The attempt to show the New Russians as latter day heroes is taken further by Dykhovychny. He certainly does not share Yevstigneyev's romantic concept of them as knights of sorts imposing their tough code on the unruly post-communist jungle. But he does believe they are tragic figures, and victims of unpredictable times. Again, the story is irrelevant -- a certain Larin (Montréal's own Grigory Hlady), a successful artist, returns to his native post-perestroika St. Petersburg after years in emigration. In the wake of his unexpected return, he becomes a reluctant participant in a succession of dramatic events. His still beautiful but neurotic 
former mistress (Dark Eyes' Elena Safonova) has married a rich, bully-like businessman, who is permanently drunk and suicidal. The mistress's daughter has grown into a beautiful, but arrogant creature. No one else on the scene is any better, including the artist himself, who cherishes a guilty passion for the daughter. The characters, as in Limita, are undergoing their existential crisis clad in expensive designer clothes, driving luxurious cars, dining under the watchful eye of bodyguards, and served by maids.

The suicidal New Russian finally succeeds in killing himself, the mistress goes mad on account of a suddenly awoken conscience, the artist dies as a collateral victim in a restaurant shoot-out. The greedy daughter is punished by losing control of her stepfather's estate. ..

The story thus told discloses a life whose cynicism could be summarised in Chekhov's famous expression: "Ours is a pathetic life, gentlemen." But the exquisite imagery openly admires this lush life style, sabotaging the analysis of the narrative. (It is not coincidental that both Limita and Music For December are shot by Sergei Kozlov, the most fashionable D.O.P. in Russia). Instead of conveying the idea of a deserted innercity jungle, Kozlov's vision of post-Soviet St. Petersburg acquires the romantic allure of an exciting urban frontier, up for grabs. Instead of suggesting spiritual homelessness, the images of expensive dachas, studios and home interiors under (re)construction convey the promising thrill of new money.

This time around Dyckhovychny, one of the masters of the conceptual remake, was misguided in his attempt to criticise a phenomenon using its own imagery. The scrupulous reconstruction of the totalitarian facade with its monumental architecture, brightly lit by the sun; with elegant fashionable clothes, and optimistic songs and dances, served as a powerful counterpoint to the brutal destruction of human lives in Moscow Parade (1992). But what worked there has failed in Music For December. Unlike their totalitarian predecessors, New Russians are neither respected nor feared. Unlike the Soviet communist elite, they lack a sense of mission and ideology to build their own culture. Unlike Stalinists, the New Russians emulate Western life style, and are transfixed by Western consumer myths. At best, they could be ridiculed and at worst -- envied. In any case, they are too greedy to qualify as romantic heroes and too cynical for tragic demons.

\section{The Classic Film Genres and the New Russian Poor}

If the films discussed above allow for a glimpse into the New Russian life at the top, a significantly larger group of films opens a broader window into the life of the New Russian poor. The life of the lower classes is viewed suitably in "lower" genre forms. These genre forms are not always "pure"; professionalism and taste are not always their strong points, but they offer ample sociological evidence about the frustrations and contemporary mythology of ordinary Russians. In spite of their genre diversity, they basically fit in this generalised scheme: an emigrant (or a visitor) arrives from the West. He/she provokes -- or witnesses -- a string of melodramatic or burlesque events, and then resolves them as deus ex machina.

In the burlesque comedy Everything Will Be OK (Dmitri Astrakhan, 1995), a rich New Russian visits his high-school flame after many years with his son -- a mathematician, and a Nobel Prize winner (sic!). The son falls in love at first sight with the daughter of the flame. The girl, however, is about to marry the boy next door. The businessman resolves the problems of the numerous inhabitants of the tumbling communal apartment block, his son gets the girl with the blessing of the boy next door, and everybody lives happily ever after. Some, like the newlyweds in America with lots of money. Others, like the boy next door, with humble salary in a run-down St. Petersburg's factory.

In Moscow Vacation, a romantic comedy directed by Alla Surikova (1995), a beautiful Italian comes to Moscow to bury her Russian grandmother's favourite dog, falls in love with a handsome taxi-driver, and after series of not-so-hilarious events, sneaks him on the plane with her.

In the melodrama American Daughter (Karen Shakhnazarov, 1995), this pattern is turned upside down: A Russian father arrives in California to visit his daughter who lives with his ex-wife and her rich American husband. Happiness is not a question of money, the director suggests, and the warmth of the Russian babushka is much more precious to the girl than all the expensive toys, private schools and fashionable clothes. Therefore she clings to her poor Russian father, and helps him organise her own abduction. On their way to Russia they get arrested at the Mexican border, the father is imprisoned for trespassing and kidnapping, and here the film ends. The escape from prison by helicopter, flown by the daughter, is from another opera. 
Even this brief revision of the plots reveals the depths of social desperation of the New Russian poor. Everything Will Be OK is a rather ironic title for a film which is no more than a catalogue of Russia's most painful social issues: alcoholism, violent crime, unemployment, prostitution, lack of perspective for the young and security for the old, horrifying poverty. It takes nothing short of a miracle to resolve a problem -any problem. From taking an elderly invalid in wheelchair down the stairs to attending a ballet performance to curing a violent alcoholic. And the princes and princesses who perform these miracles are in short supply, and, as they say in Russian, all ot tuda, from the affluent West. Russia's own nouveaux riches are just beginning to provide their share of miracle makers, but the demand -- as in any area of post-communist Russian economics -- exceeds the supply.

Usually melodramas cater to women's unfulfilled desires. But Moscow Vacation and American Daughter could be understood as attempts (although rather unconvincing in both artistic and sociological sense) to restore the waning self-esteem of Russian men. Moscow Vacation offers the consolation of the sexual triumph of a Russian man, who takes a beautiful Italian by storm. But sexual self-realisation has never been a singular priority for Russian men. Many of them feel frustrated for lacking the "special" qualities required to become New Russians, and are ready to identify with the humiliation, suffered by their country with the loss of its super-power status. They take the downfall of their country as proof of their double failure -- at home and abroad. In this sense American Daughter is a melodrama for men, geared to their anxieties and hurt pride. Its ending represents a threefold triumph -- emotional, social and patriotic. The Russian father wins his daughter over her mother, her social status, and affluent America. The last being his sweetest triumph.

Soviet cinema has been predominantly male-oriented since the early 1930s. The films on women's issues were most often made by male directors. Only during late 1970s and 1980s there appeared a few women directors, who presented the Soviet reality through female gaze and perception. That is why the images of women did not suffer great transformation in post-Soviet Russian cinema -- they are there to help their men out, to support and love them, humble and submissive, traditionally "feminine". For refusing to stand by her husband, a drunk, professional failure and a petty criminal, the mother and ex-wife from American Daughter is pictured as an evil woman. A beautiful vamp who dared marry a foreigner and build a new life for herself and her daughter is expected to be despised by the Russian audiences.

Russian perestroika film culture has boasted inclusive egalitarianism until recently. The leap it has taken to cheap melodramas and sentimental comedies, preying on basic escapist myths about male and female cinderellas, actually matches the leap Russia took from super power to impoverished third world country.

Against this bleak backdrop one is tempted to look for sociological revelations, complicated messages and a cross-section of the "mysterious" Russian soul everywhere, even in the hilariously funny adventures of a student from Finland on an academic research trip to present-day Russia (Peculiarities of Russian Hunt, A. Rogozhkun, 1995). In such an atmosphere, even the good-natured humour and inventive gags of this very humane film could look ominous: the Finn gets attached to a diverse social group of seasoned hunters, but they hardly ever fire a gun. He has come to research the customs of modern hunting in Russia, but all he does is drink himself silly in the company of his Russian friends. The only harmonious vision, inserted into this surreal alcoholic nightmare, are his serene dreams of an $18^{\text {th }}$ century stylish hunting event. Who knows, maybe there is some moral in this. But what?

\section{Notes}

1. Other films from that iconoclast series include Tractorists-2 (Aleynikov Bros, 1990), Captives Of Luck (M. Pezhemsky, 1992), The Dreams Of An Idiot (Vasily Pichul, 1991) and Over The Dark Waters (D. Meskhiev, 1993).

\section{Author Information}

Christina STOJANOVA teaches at the Department of Media Production and Studies at the University of Regina, Canada. She has contributed to Cine-bulles, KinoKultura, and the Montreal Gazette. Her publi- 


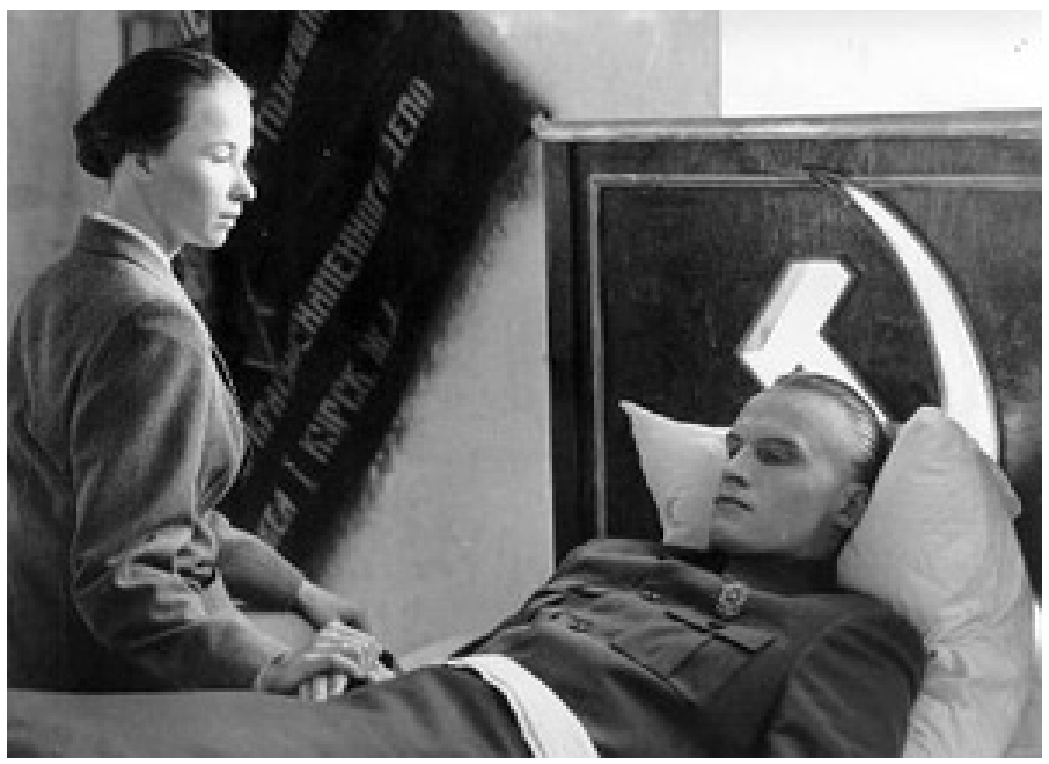

Figure 1: Hammer and Sickle by Sergei Livnev

cations include chapters in Berlin Culturescapes, Making it Like a Man: Canadian Masculinities, Eastern European Cinema, Traditions in World Cinema, Horror International, Alternative Europe and Cinema and Globalization. 